\title{
ANALISIS FINANCING TO DEPOSIT RATIO, DEBT TO EQUITY RATIO, RETURN ON EQUITY DAN QUICK RATIO TERHADAP PEMBIAYAAN MURABAHAH PADA BANK UMUM SYARIAH DI INDONESIA
}

\author{
Diah Nurdiwaty \\ Fakultas Ekonomi Universitas Nusantara PGRI Kediri \\ ardh_olivia@yahoo.com \\ Faisol \\ Fakultas Ekonomi Universitas Nusantara PGRI Kediri \\ faisol@unpkediri.ac.id
}

\begin{abstract}
Murabaha financing is a form of channeling funds of Islamic banks in transaction using the contract of sale and purchase of goods, where the selling price at cost plus agreed profit and the seller must disclose the acquisition cost of the goods to the buyer, the payment of Murabaha can be made by cash or deferred / credit, This study was conducted to analyze the effect of Financing to Deposit Ratio (FDR), Debt To Equity Ratio (DER), Return on Equity (ROE) and the Quick Ratio (QR) on the financing Murabaha of Islamic Banks in the period of 2012-2015. Data analysis technique used is multiple linear regression analysis with a confidence level of 5\%. The data used is secondary data obtained from the publication of the quarterly financial statements are recorded in the Bank Indonesia (BI). This study uses quarterly reports the population of the entire Islamic Banks registered in Bank Indonesia (BI) in 2012-2015 a total of 11 Islamic banks. The sampling technique used was purposive sampling were then obtained 64 samples of the quarterly financial statements. The results showed that partially FDR, ROE and QR significant and positive impact on the financing murabaha, while DER has significant and negative effect on murabaha financing. Based on $F$ test showed that the FDR, DER, ROE and QR simultaneously affect the financing murabaha, the influence of these four variables independet was $43.7 \%$ and the remaining $56.3 \%$ influenced by other variables outside the research. Based on the conclusions on the outcome of this study, the authors suggest that in the decision the distribution of murabaha financing not only consider Financing to Deposit Ratio (FDR), Debt To Equity Ratio (DER), Return on Equity (ROE) and the Quick Ratio (QR), but should consider other factors, so that the decision could be more precise and accurate.
\end{abstract}

Keywords: Murabahah, Financing to Deposit Ratio (FDR), Debt To Equity Ratio (DER), Return on Equity (ROE), Quick Ratio (QR). 


\section{PENDAHULUAN}

\section{Latar Belakang}

Perekonomian di Indonesia sangat bergantung kepada bank, karena bank menawarkan jasa perkreditan dan jasa keuangan lain yang melayani kebutuhan usaha bagi semua sektor perekonomian, selain itu bank juga menawarkan sistem pembayaran bagi semua sektor perekonomian, bank juga menjadi tempat yang aman dalam menyimpan dana bagi perusahaan, badan-badan usaha milik pemerintah, maupun swasta. Kebutuhan akan jasa bank yang semakin tinggi mendorong munculnya berbagai jenis bank, salah satunya adalah bank syariah.

Menurut Undang-Undang No. 21 tahun 2008 tentang perbankan syariah, menyatakan bahwa Perbankan Syariah adalah segala sesuatu yang menyangkut tentang Bank Syariah dan Unit Usaha Syariah, mencakup kelembagaan, kegiatan usaha, serta cara dan proses dalam melaksanakan kegiatan usahanya. Pesatnya perkembangan sistem ekonomi syariah di Indonesia saat ini, terutama di lembaga keuangan ditandai dengan berdirinya Bank Muamalat Indonesia tahun 1992. Hal ini merupakan bukti "sehatnya" sistem yang dikembangkan ekonomi Islam.

Pertumbuhan dan perkembangan yang pesat di bidang keuangan syariah ini tentu saja membuka peluang bagi bank syariah untuk juga ikut lebih aktif didalam mensukseskan perekonomian Indonesia. Pengalaman di masa krisis menunjukkan bahwa bank syariah terbukti mampu bertahan dari berbagai guncangan dan relatif tidak membutuhkan banyak bantuan pemerintah. Ini berarti bahwa upaya pengembangan lembaga keuangan syariah juga sekaligus akan membantu ketahanan perekonomian nasional. Untuk itu, harus didesain kebijakan pemerintah yang mendukung perkembangan dan pertumbuhan lembaga keuangan syariah, sekaligus memungkinkan lahirnya pemikiran-pemikiran dari para ahli ekonomi untuk menghasilkan konsep atau teori ekonomi Islam yang betul-betul sejalan dengan hukum Islam.

Menurut data yang diperoleh dari laporan Statistik Perbankan Syariah per April 2015 yang diterbitkan oleh Bank Indonesia (BI), menunjukkan perkembangan bank syariah yang pesat di Indonesia. Secara kuantitas, bank syariah terus mengalami peningkatan dalam jumlah bank. 
Perekonomian nasional maupun internasional yang senantiasa bergerak cepat disertai tantangan yang semakin luas, maka sangat penting untuk dilakukan suatu antisipasi, dalam rangka menampung aspirasi dan kebutuhan masyarakat untuk menyelenggarakan kegiatan usaha berdasarkan prinsip syariah yang mulai marak. Bank dengan prinsip syariah lahir dengan dilatarbelakangi oleh kebutuhan masyarakat khususnya sebagian umat Islam Indonesia terhadap bank tanpa bunga, kelahiran bank syariah di Indonesia yang menggunakan sistem bank tanpa bunga telah membawa pengaruh yang signifikan terhadap sistem perbankan Indonesia karena konsep bunga pada bank konvensional oleh sebagian umat Islam Indonesia dianggap sebagai riba yang hukumnya haram. Prinsip bank syariah seperti halnya bank konvensional, juga berfungsi sebagai suatu lembaga intermediasi (intermediary institution), yaitu mengerahkan dana dari masyarakat dan menyalurkan kembali dana tersebut kepada masyarakat yang membutuhkannya dalam bentuk fasilitas pembiayaan.

Bersamaan dengan meningkatnya pertumbuhan ekonomi di Indonesia, jumlah pembiayaan bank syariah juga mengalami peningkatan yang tajam. Kualitas pembiayaan bank syariah juga menunjukkan kinerja yang membaik dengan ditunjukkan oleh semakin besarnya porsi pembiayaan. Bank syariah menawarkan berbagai produk pembiayaan yang sangat menarik. Ada 8 macam pembiayaan pada bank syariah, yaitu akad wadiah, akad mudharabah, akad musyarakah, akad murabahah, akad salam, akad istishna, akad ijarah, dan akad qardh. Pembiayaan tersebut berasal dari bank umum syariah dan unit usaha syariah yang terdaftar pada Bank Indonesia. Menurut data yang diperoleh dari Bank Indonesia menunjukkan bahwa dari kedelepan pembiayaan yang biberikan oleh bank syariah, akad murabahah menjadi yang tertinggi, dari tahun 2010 sampai 2014 lebih dari 55\% pembiayaan yang diberikan melalui akad murabahah, dan sisanya diberikan melalui akad wadiah, akad mudharabah, akad musyarakah, akad salam, akad istishna, akad ijarah, dan akad qardh.

Menurut PSAK No. 102 tentang Akuntansi Murabahah, menyatakan bahwa murabahah adalah akad jual beli barang dengan harga jual sebesar biaya perolehan ditambah keuntungan yang disepakati dan penjual harus mengungkapkan biaya perolehan barang tersebut kepada pembeli. Dalam PSAK No. 102 tentang Akuntansi Murabahah, disebutkan bahwa pembayaran murabahah dapat dilakukan secara tunai atau tangguh. Pembayaran 
tangguh adalah pembayaran yang dilakukan tidak pada saat barang diserahkan kepada pembeli, tetapi pembayaran dilakukan secara angsuran atau sekaligus pada waktu tertentu.

Menurut Pratin dan Akhyar (2005:36) salah satu faktor yang mempengaruhi jumlah pembiayaan yang disalurkan oleh bank syariah adalah faktor internal, salah satunya adalah rasio-rasio keuangan bank syariah meliputi rasio likuiditas, profitabilitas, solvabilitas dan aktivitas. Di sini penelitian akan mencoba menggunakan beberapa faktor internal bank syariah yang berpengaruh terhadap pembiayaan murabahah, yaitu Financing To Deposit Ratio (FDR), Debt To Equity Ratio (DER), Return On Equity (ROE) dan Quick Ratio (QR). Hal ini juga didukung oleh hasil-hasil riset terdahulu, antara lain penelitian Cleopatra (2008) menunjukkan bahwa variabel FDR secara negatif signifikan mempengaruhi pembiayaan bank syariah. Maula (2009) dalam penelitiannya menemukan bahwa NPF berpengaruh secara negatif dan signifikan terhadap pembiayaan murabahah. Dan juga Arbaian (2008) menemukan secara parsial Debt To Equity Ratio (DER) berpengaruh negatif dan tidak signifikan, sedangkan Quick Ratio (QR) berpengaruh positif dan signifikan terhadap pembiayaan murabahah serta Return On Equity (ROE) berpengaruh positif dan tidak signifikan terhadap pembiayaan murabahah.

\section{Rumusan Masalah}

Berdasarkan latar belakang yang telah diuraikan, maka dapat dirumuskan permasalahan sebagai berikut: 1) Apakah Financing To Deposit Ratio (FDR) secara parsial berpengaruh terhadap pembiayaan murabahah pada Bank Umum Syariah tahun 2012-2015? 2). Apakah Debt To Equity Ratio (DER) secara parsial berpengaruh terhadap pembiayaan murabahah pada Bank Umum Syariah tahun 2012-2015? 3). Apakah Return On Equity (ROE) secara parsial berpengaruh terhadap pembiayaan murabahah pada Bank Umum Syariah tahun 2012-2015? 4). Apakah Quick Ratio (QR) secara parsial berpengaruh terhadap pembiayaan murabahah pada Bank Umum Syariah tahun 2012-2015? 5). Apakah Financing To Deposit Ratio (FDR), Debt To Equity Ratio (DER), Return On Equity (ROE) dan Quick Ratio (QR) secara simultan berpengaruh terhadap pembiayaan murabahah pada Bank Umum Syariah tahun 2012-2015?

\section{Tujuan Penelitian}


Adapun yang menjadi tujuan penelitian ini adalah : 1) Untuk menganalisis pengaruh secara parsial Financing To Deposit Ratio (FDR) terhadap pembiayaan murabahah pada Bank Umum Syariah tahun 2012-2015, 2) Untuk menganalisis pengaruh secara parsial Debt To Equity Ratio (DER) terhadap pembiayaan murabahah pada Bank Umum Syariah tahun 2012-2015, 3) Untuk menganalisis pengaruh secara parsial Return On Equity (ROE) terhadap pembiayaan murabahah pada Bank Umum Syariah tahun 2012-2015, 4) Untuk menganalisis pengaruh secara parsial Quick Ratio (QR) terhadap pembiayaan murabahah pada Bank Umum Syariah tahun 2012-2015, 5) Untuk menganalisis pengaruh Financing To Deposit Ratio (FDR), Debt To Equity Ratio (DER), Return On Equity (ROE) dan Quick Ratio (QR) secara simultan terhadap pembiayaan murabahah pada Bank Umum Syariah tahun 20122015. Penelitian ini diharapkan dapat memberikan gambaran kepada nasabah tentang kondisi kesehatan bank syariah dalam menjalankan praktik murabahah. Selain itu, penelitian ini diharapkan dapat menjadi masukan bagi pihak bank untuk meningkatkan kualitas pembiayaan murabahah.

\section{KAJIAN PUSTAKA}

\section{Perbankan Konvensional}

Berdasarkan Undang-undang No.7 Tahun 1992 tentang perbankan sebagaimana telah diubah dengan Undang-undang No.10 Tahun 1998, jenis bank di Indonesia terdiri dari dua kelompok yaitu Bank Umum dan Bank Perkreditan Rakyat (BPR). Dalam UU tersebut dijelaskan bahwa bank umum adalah bank yang melaksanakan kegiatan usaha secara konvensional dan/atau berdasarkan prinsip syariah yang dalam kegiatannya memberikan jasa dalam lalu lintas pembayaran. Dalam PSAK No. 31 dijelaskan bahwa, bank konvensional merupakan lembaga keuangan yang berperan sebagai perantara keuangan, yang menyalurkan dana dari pihak yang berkelebihan dana kepada pihak yang membutuhkan dana, serta sebagai lembaga yang perfungsi memperlancar lalu lintas pembayaran dengan bunga sebagai imbalannya.

\section{Perbankan Syariah}

Dalam Undang-undang No. 21 Tahun 2008 pasal 1 dijelaskan bahwa Bank Umum Syariah adalah bank syariah yang dalam kegiatannya memberikan jasa dalam lalu lintas 
pembayaran berdasarkan prinsip syariah, sedangkan Bank Pembiayaan Rakyat Syariah adalah bank syariah yang dalam kegiatannya tidak memberikan jasa dalam lalu lintas pembayaran. Sedangkan yang dimaksud dengan prinsip syariah dijelaskan pada pasal 1 butir 12 Undangundang tersebut adalah prinsip hukum Islam dalam kegiatan perbankan berdasarkan fatwa yang dikeluarkan oleh lembaga yang memiliki kewenangan dalam penetapan fatwa di bidang syariah.

\section{Produk Operasional Bank Syariah}

Menurut Adiwarman (2006:97), menyatakan bahwa produk yang ditawarkan oleh bank syariah dapat dibagi menjadi tiga kelompok, yaitu:

1. Produk penghimpunan dana (Funding), menerapkan prisip Wadi'ah (jasa penitipan) dan Mudharabah

2. Produk penyaluran dana (Financing) berdasar tujuannya berupa : a) Syirkah (bagi hasil), b) Ba’i (jual-beli), c) Ijarah (sewa).

3. Produk Jasa (Service) pada bank syariah yaitu: a) Alih utang-piutang (Hiwalah), b) Gadai (Rahn), c) Pinjaman kebaikan (Qardh), d) Perwakilan (Wakalah), e) Garansi Bank (Kafalah).

\section{Pembiayaan Murabahah}

Menurut PSAK No. 102 tentang Akuntansi Murabahah, menyatakan bahwa murabahah adalah akad jual beli barang dengan harga jual sebesar biaya perolehan ditambah keuntungan yang disepakati dan penjual harus mengungkapkan biaya perolehan barang tersebut kepada pembeli. pembayaran murabahah dapat dilakukan secara tunai atau tangguh. Pembayaran tangguh adalah pembayaran yang dilakukan tidak pada saat barang diserahkan kepada pembeli, tetapi pembayaran dilakukan secara angsuran atau sekaligus pada waktu tertentu.

Hal yang membedakan murabahah dengan penjualan yang biasa dikenal adalah penjual secara jelas memberitahu kepada pembeli berapa harga pokok barang tersebut dan berapa besar keuntungan yang diinginkannya. Pembeli dan penjual dapat melakukan tawar menawar atas besaran margin keuntungan sehingga akhirnya diperoleh kesepakatan.

Mekanisme murabahah, Antonio (2001:34): 


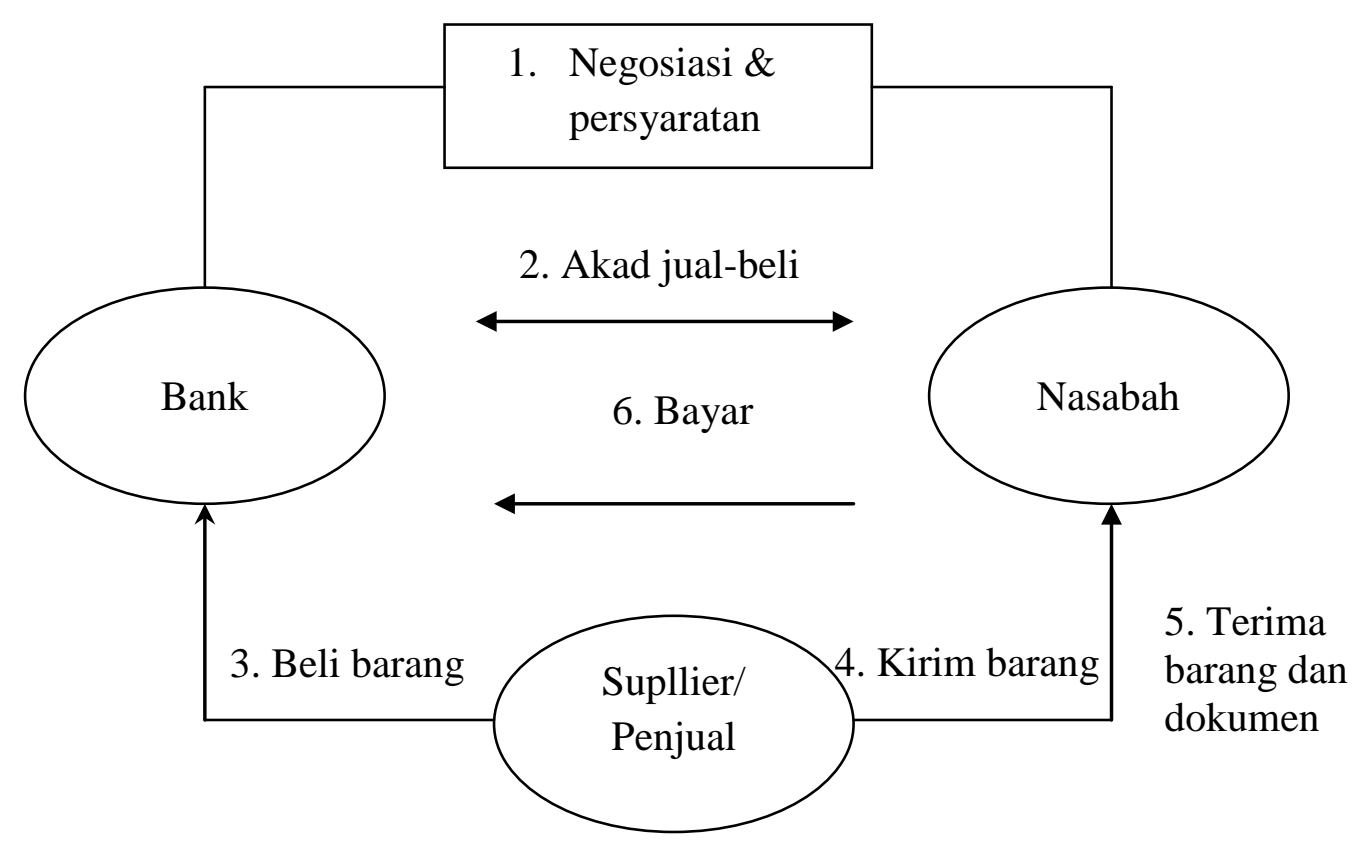

Sebagai bukti bahwa dari tahun ke tahun dana pembiayaan murabahah lebih banyak disalurkan dari pada pembiayaan yang lain, berikut ditampilkan table komposisi pembiayaan yang diberikan oleh Bank Umum Syariah :

Komposisi pembiayaan yang diberikan Bank Umum Syariah (BUS)

\begin{tabular}{|l|r|r|r|r|r|}
\hline \multicolumn{1}{|c|}{ Akad } & \multicolumn{1}{c|}{2010} & \multicolumn{1}{c|}{2011} & \multicolumn{1}{c|}{2012} & \multicolumn{1}{c|}{2013} & \multicolumn{1}{c|}{2014} \\
\hline Mudharabah & 8.631 & 10.229 & 12.023 & 13.625 & 14.354 \\
\hline Musyarokah & 14.624 & 18.960 & 27.667 & 39.874 & 49.387 \\
\hline Murabahah & 37.508 & 56.365 & 88.004 & 110.565 & 117.371 \\
\hline Salam & 0 & 0 & 0 & 0 & 0 \\
\hline Istishna & 347 & 326 & 376 & 582 & 633 \\
\hline Ijarah & 2.341 & 3.839 & 7.345 & 10.481 & 11.620 \\
\hline Qardh & 4.731 & 12.937 & 12.090 & 8.99 & 5.965 \\
\hline Lainnya & 0 & 0 & 0 & 0 & 0 \\
\hline
\end{tabular}

Sumber : Bank Indonesia 


\section{Faktor-faktor yang Mempengaruhi Pembiayaan Murabahah.}

Menurut Pratin dan Akhyar (2005:36) ada dua faktor yang mempengaruhi jumlah pembiayaan yang disalurkan oleh bank syariah yaitu:

1. Faktor eksternal antara lain: a)Kompetisi dari lembaga keuangan lainnya, b) Hukum dan peraturan mengenai lembaga keuangan, c) kebijakan pemerintah yang mempengaruhi sistem ekonomi dan keuangan.

2. Faktor internal antara lain: a) Efisiensi penggunaan sumber daya, b) Pengendalian biaya, c) Kebijakan manajemen perpajakan, d) Posisi risiko dan posisi likuiditas yang ditunjukkan oleh: 1) Financing To Deposit Ratio (FDR), 2) Debt To Equity Ratio (DER), 3) Return On Equity (ROE), 4) Quick Ratio (QR)

\section{Financing to Deposit Ratio (FDR)}

Menurut Lukman Dendawijaya (2005:116) menyatakan bahwa Financing to Deposit Ratio (FDR) adalah rasio antara seluruh jumlah kredit yang diberikan bank dengan dana yang diterima oleh bank. Dapat dikatakan bahwa FDR merupakan rasio yang menunjukkan kemampuan bank didalam menyediakan dana kepada debiturnya dengan dana yang dikumpulkan dari masyarakat, yang artinya semakin tinggi rasio tersebut memberikan indikasi semakin tingginya kemampuan bank dalam pembiayaan yang disalurkan.

\section{Debt to Equity Ratio (DER)}

Rasio ini menggambarkan sampai sejauh mana modal pemilik dapat menutupi utang-utang kepada pihak luar. Semakin kecil rasio ini semakin baik. Rasio ini disebut juga rasio leverage. Untuk keamanan pihak luar rasio terbaik jika modal lebih besar dari jumlah utang atau minimal sama. Namun bagi pemegang saham atau manajemen rasio leverage ini sebaiknya besar, Harahap (2010:303). Debt to Equity Ratio pada setiap perusahaan tentu berbeda-beda, tergantung karakteristik bisnis dan keberagaman arus kasnya. Perusahaan dengan arus kas yang stabil biasanya memiliki rasio yang lebih tinggi dari rasio kas yang kurang stabil.

\section{Return on Equity (ROE)}

Menurut Sartono (2010:124) menyatakan : “Return on Equity mengukur kemampuan perusahaan memperoleh laba yang tersedia bagi pemegang saham perusahaan. Rasio ini juga 
dipengaruhi dengan besar kecilnya hutang perusahaan apabila proporsi hutang semakin besar maka rasio ini juga akan semakin besar”. Semakin besar ROE, semakin besar pula tingkat keuntungan yang dicapai bank sehingga kemungkinan suatu bank dalam kondisi bermasalah semakin kecil.

\section{Quick Ratio (QR)}

Menurut Sutrisno (2001:53), Quick Ratio (QR) merupakan rasio antara aktiva lancar setelah dikurangi persediaan dengan hutang lancar. Rasio ini merupakan ukuran kemampuan perusahaan dalam memenuhi kewajiban-kewajibannya dengan tidak memperhitungkan persediaan, karena persediaan memerlukan waktu yang relatif lama untuk direalisir menjadi uang kas. Rasio ini hampir sama dengan current ratio hanya saja jumlah persediaan (inventory) sebagai salah satu komponen dari aktiva lancar harus dikeluarkan. Alasan yang melatarbelakangi hal tersebut adalah bahwa persediaan merupakan komponen aktiva lancar yang pailng tidak likuid atau sulit untuk diuangkan dengan segera tanpa menurunkan nilainya, sementara dengan Quick Ratio (QR) dimaksudkan untuk membandingkan aktiva yang lebih lancar dengan utang lancar.Semakin tinggi rasio tersebut semakin tinggi pula kemampuan suatu perusahaan untuk melunasi hutang jangka pendeknya yang jatuh tempo dengan tepat waktu.

\section{Hipotesis}

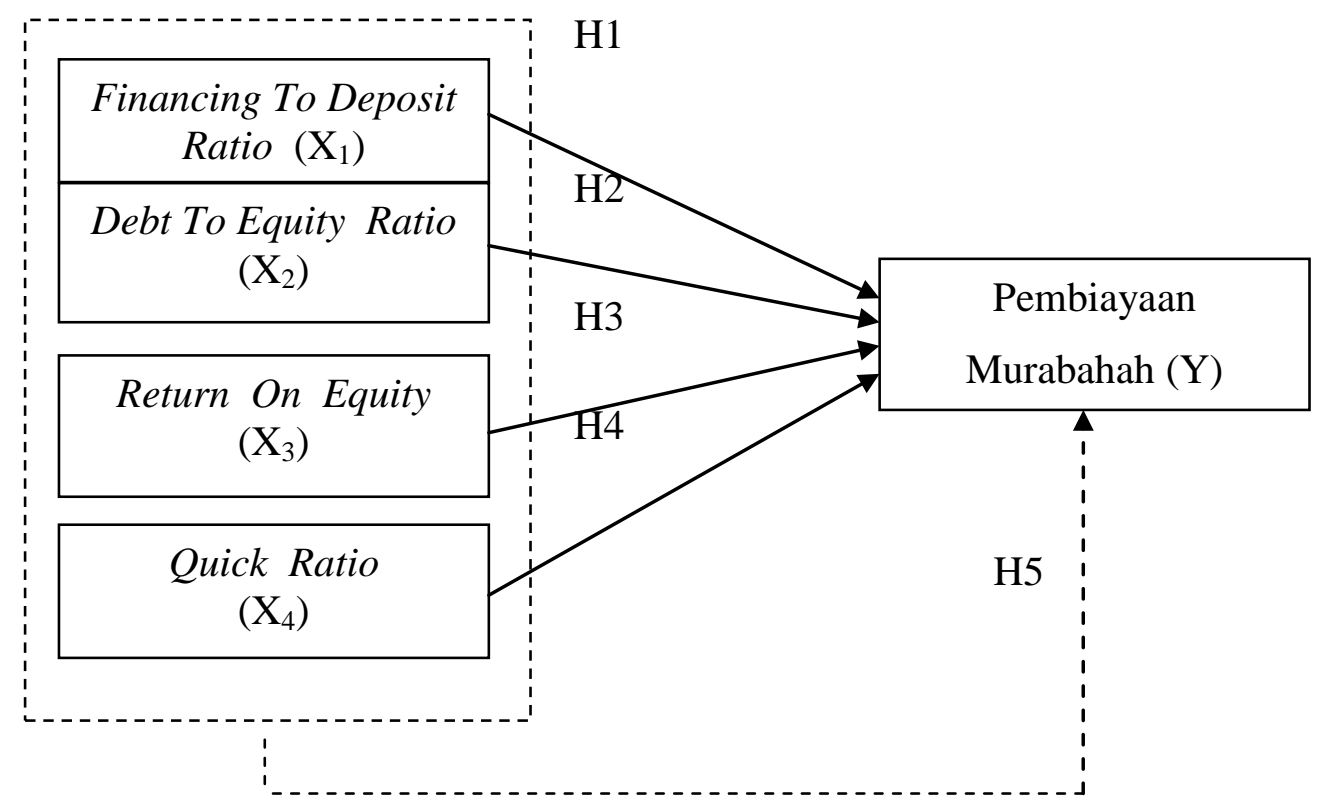


Keterangan:

$\begin{array}{ll}\longrightarrow & \text { Pengaruh secara parsial } \\ & \text { Pengaruh secara simultan (bersama-sama) }\end{array}$

$\mathrm{H}_{1}$ : Financing To Deposit Ratio (FDR) secara parsial berpengaruh terhadap pembiayaan murabahah pada Bank Umum Syariah tahun 2012-2015

$\mathrm{H}_{2}$ : Debt To Equity Ratio (DER) secara parsial berpengaruh terhadap pembiayaan murabahah pada Bank Umum Syariah tahun 2012-2015.

$\mathrm{H}_{3}$ : Return On Equity (ROE) secara parsial berpengaruh terhadap pembiayaan murabahah pada Bank Umum Syariah tahun 2012-2015.

$\mathrm{H}_{4}$ : Quick Ratio (QR) secara parsial berpengaruh terhadap pembiayaan murabahah pada Bank Umum Syariah tahun 2012-2015.

$\mathrm{H}_{5}$ : Financing To Deposit Ratio (FDR), Debt To Equity Ratio (DER), Return On Equity (ROE) dan Quick Ratio (QR) secara simultan berpengaruh terhadap pembiayaan murabahah pada Bank Umum Syariah tahun 2012-2015.

\section{METODE PENELITIAN}

\section{Populasi dan Sampel}

Teknik penelitian yang digunakan dalam penelitian ini adalah teknik statistik deskriptif dan jenis penelitian yang digunakan adalah jenis penelitian ex post facto.

Populasi dalam penelitian ini adalah seluruh bank syariah yang tergabung dalam Bank Umum Syariah periode waktu 2012-2015 dimana data diperoleh dari website resmi Bank Indonesia di www.bi.go.id dengan jumlah populasi sebanyak 11 bank. penulis menggunakan sampel laporan keuangan dari bank syariah yang sesuai kriteria untuk periode tahun 2012-2015 dan perusahaan yang terpilih ada 4 bank syariah.

Laporan keuangan yang dikeluarkan oleh keempat bank syariah tersebut merupakan laporan keuangan triwulan, jadi dalam periode tahun 2012-2015 terdapat 16 laporan keuangan, maka laporan keuangan yang dijadikan sampel sebanyak (4x16) 64 data sampel. Adapun kriteria-kriteria pengambilan sampel dalam penelitian ini adalah sebagai berikut:

a. Bank syariah yang tergabung dalam Bank Umum Syariah.

b. Bank syariah yang secara konsisten menyajikan laporan keuangan triwulan pada periode tahun 2012-2015 dan telah diaudit oleh kantor akuntan publik. 


\section{Definisi Operasional}

Dalam penelitian ini menggunakan variable terikat (dependen) adalah pembiayaan murabahah(Y). Sementara variabel bebas atau independen variable merupakan variabel yang mempengaruhi dan yang menjadi sebab perubahan variabel terikat adalah: 1) Financing To Deposit Ratio $\left.\left(\mathrm{X}_{1}\right), 2\right)$ Debt To Equity Ratio $\left(\mathrm{X}_{2}\right)$, 3) Return On Equity $\left(\mathrm{X}_{3}\right)$, 4) Quick Ratio $\left(\mathrm{X}_{4}\right)$

\section{Teknik Analisis Data}

Teknik analisis data yang digunakan dalam penelitian ini adalah :

\section{Analisis Deskriptif}

Analisis deskriptif ini digunakan sebagai pendukung untuk menambah dan mempertajam analisis yang dilakukan, membantu memahami masalah yang diteliti serta memberikan gambaran umum tentang suatu fenomena yang terjadi.

2. Uji Asumsi Klasik

Uji asumsi klasik adalah persyaratan statistik yang harus dipenuhi pada analisis regresi berganda. Uji asumsi klasik yang cepat terjadi dalam penggunaan model regresi yaitu:

a. Uji normalitas

Bertujuan untuk menguji apakah dalam model regresi, variabel pengganggu atau residual memiliki distribusi normal. Untuk menganalisis normalitas bisa juga menggunakan uji Kolmogorov-Smirnov (K-S). Dari Uji K-S dibuat dengan membuat hipotesis $\mathrm{H}_{0}$ : Data residual berdistribusi normal, $\mathrm{H}_{\mathrm{a}}$ : Data residual tidak berdistribusi normal. Keputusan yang dapat diambil yaitu: Bila signifikansi $>0,05$ dengan $\alpha=5 \%$ berarti distribusi data normal dan $\mathrm{H}_{0}$ diterima, sebaliknya bila nilai signifikan $<0,05$ berarti distribusi data tidak normal dan $\mathrm{H}_{\mathrm{a}}$ diterima.

b. Uji multikoleniaritas.

Bertujuan untuk menguji apakah model regresi ditemukan adanya korelasi antar variabel bebas atau independen. Apabila terjadi korelasi antara variabel bebas, maka terdapat problem multikolinieritas (multiko) pada model regresi tersebut. Deteksi adanya multikolineriaritas sebagai berikut: 
1) Besaran VIF (variance inflation factor) dan Tolerance Model regresi yang bebas multikolinearitas adalah :a)Mempunyai nilai VIF disekitar angka 1, b) Mempunyai angka tolerance mendekati 1.

2) Besaran kolerasi antar variabel independen.

Menurut (Santoso, 2004:207) Pedoman suatu model regresi yang bebas multikolinearitas adalah koefisien korelasi antar variabel independen haruslah lemah di bawah 0,05. Jika korelasi kuat maka terjadi problem multikolinearitas

c. Uji heteroskedastisitas

Bertujuan untuk menguji apakah dalam model regresi terjadi ketidaksamaan variance dari residual satu pengamatan ke pengamatan lain, jika variance dari residual satu pengamatan ke pengamatan lain berbeda maka disebut heteroskedastisitas. Deteksi dilakukan dengan melihat ada tidaknya pola tertentu dalam grafik dimana sumbu $\mathrm{X}$ dan $\mathrm{Y}$ telah diproduksi. dasar pengambilan keputusan adalah sebagai berikut.

1) Jika titik-titik yang ada membentuk suatu pola tertentu yang teratur seperti gelombang, melebar, kemudian menyempit, maka terjadi heteroskedastisitas.

2) Jika titk-titik ada pola yang jelas, serta titik-titik menyebar di atas dan di bawah angka 0 pada sumbu Y, maka tidak terjadi heteroskedastisitas, Ghozali (2011:170)

d. Uji autokorelasi.

Bertujuan menguji apakah dalam model regresi ada korelasi antara kesalahan pengganggu pada periode t dengan kesalahan pengganggu pada periode t-1 atau sebelumnya. Menguji apakah dalam sebuah regresi linier ada korelasi antara kesalahan penggangu pada periode t-1 sebelumnya. Jika terjadi korelasi, maka dinamakan ada problem autokorelasi. Biasanya hal ini terjadi pada regresi yang datanya adalah time series atau berdasarkan waktu berkala. Metode Durbin Watson bisa juga digunakan untuk menetukan autokorelasi. Menurut Ghozali (2011:183) Kriteria pengambilan keputusan Metode Durbin Watson adalah sebagai berikut:

$$
\begin{array}{ll}
0<\mathrm{d}<\mathrm{dL} & =\text { Ho ditolak } \\
\mathrm{dL} \leq \mathrm{d} \leq \mathrm{du} & =\text { Daerah keraguan/tanpa keputusan } \\
\mathrm{du} \leq \mathrm{d} \leq(4-\mathrm{du}) & =\text { Ho diterima }
\end{array}
$$




$$
\begin{array}{ll}
(4-\mathrm{du}) \leq \mathrm{d} \leq(4-\mathrm{dL}) & =\text { Daerah keraguan/tanpa keputusan } \\
(4-\mathrm{dL}) \leq \mathrm{d} \leq 4 & =\text { Ho ditolak }
\end{array}
$$

\section{Uji Hipotesis}

Uji regresi merupakan suatu teknik uji statistik yang dapat digunakan untuk menganalisis hubungan antara variabel dependen dengan variabel independen. Dalam penelitian ini digunakan analisis regresi linier berganda untuk melakukan prediksi, bagaimana perubahan nilai variabel dependen bila nilai variabel independen dinaikan atau diturunkan nilainya.Peneliti menggunakan analisis ini untuk mengetahui kuatnya hubungan antara beberapa variabel bebas secara serentak terhadap variabel terkait dan dinyatakan dengan rumus analisis regresi linier berganda sebagai berikut:

$Y=a+\beta_{1} X_{1}+\beta_{2} X_{2}+\beta_{3} X_{3}+\beta_{2} X_{4}$

4. Koefisien Determinasi

Menurut Ghozali (2011:190) Koefisien determinasi $\left(\mathrm{R}^{2}\right)$ pada intinya mengukur seberapa jauh kemampuan mode dalam menerangkan variasi variabel dependen. rumus sebagai berikut:

$$
\mathrm{R}^{2}=\text { Adjusted R-Square } \times 100 \%
$$

Jika nilai $\mathrm{R}^{2}$ mendekati 0 berarti kemampuan variabel independen dalam menjelaskan variasi variabel dependen amat terbatas sedangkan nilai yang mendekati 1 berarti variabel-variabel independen memberikan hampir semua informasi yang dibutuhkan untuk memprediksi variasi variabel dependen.

Uji Hipotesis yang dilakukan meliputi :

a) Uji t (Uji Parsial), yaitu untuk menguji apakah variabel independen secara individu berpengaruh terhadap variabel dependen. Jika probabilitas $>0,05$ maka $\mathrm{H}_{0}$ diterima dan $\mathrm{H}_{\mathrm{a}}$ ditolak, jika probabilitas $<0,05$ maka $\mathrm{H}_{0}$ ditolak dan $\mathrm{H}_{\mathrm{a}}$ diterima.

b) Uji F (Uji Simultan), digunakan untuk menguji pengaruh variabel independen secara bersama-sama terhadap variabel dependen dari suatu persamaan regresi dengan menggunakan hipotesis statistik. Kriteria pengambilan keputusan Uji F 
adalah Jika probabilitas $>0,05$ maka $\mathrm{H}_{0}$ diterima dan $\mathrm{H}_{\mathrm{a}}$ ditolak, jika probabilitas $<0,05$ maka $\mathrm{H}_{0}$ ditolak dan $\mathrm{H}_{\mathrm{a}}$ diterima.

Untuk pengolahan data digunakan program komputer Statistical Package Sosial Science.

\section{ANALISIS DAN PEMBAHASAN}

\section{Analisis Deskriptif.}

Dari data yang diteliti berjumlah 64 diperoleh hasil sebagai berikut :

\begin{tabular}{|c|c|c|c|}
\hline No & Rasio & Nilai rata-rata & Dinyatakan sehat oleh BI \\
\hline 1 & FDR & 93.92 & $88 \%-110 \%$ \\
\hline 2 & DER & 29.28 & $>8 \%$ \\
\hline 3 & ROE & 33.48 & $>12 \%$ \\
\hline 4 & QR & 30.28 & $>10 \%$ \\
\hline
\end{tabular}

Hasil tersebut menunjukkan bahwa rasio-rasio dari bank syariah sampel yang diteliti tergolong bank yang dinyatakan sehat oleh Bank Indonesia.

\section{Hasil Uji Normalitas.}

Dari uji Kolmogrov-Smirnov test (K-S)ditunjukkan nilai signifikansi residual variabel sebesar 0,200 yang artinya lebih besar dari taraf signifikansi yang ditetapkan sebesar 0,05, dari hasil tersebut menunjukkan bahwa data terdistribusi normal.

\section{Uji Multikolonieritas}

Hasil uji multikolonieritas dapat diketahui bahwa masing-masing variabel memiliki nilai Tolerance dan VIF sebagai berikut: FDR memiliki nilai Tolerance 0,762 dan VIF 1,313 = tidak multikolinier, DER memiliki nilai Tolerance 0,831 dan VIF 1,204 = tidak multikolinier, ROE memiliki nilai Tolerance 0,726 dan VIF 1,359 = tidak multikolinier, QR memiliki nilai Tolerance 0,735 dan VIF 1,361 = tidak multikolinier.

Dengan demikian dalam penelitian ini tidak ada multikolineritas karena memenuhi dasar pengambilan keputusan yaitu keempat variabel independen yang diteliti memiliki nilai Tolerance $>0,10$ dan nilai VIF $<10,00$.

\section{Uji Heteroskedastisitas}

Hasil uji heteroskedastiritas diperoleh grafik scatterplot dengan titik-titik menyebar secara acak dan tidak menujukkan pola tertentu, tersebar baik diatas maupun dibawah angka nol pada sumbu Y. hal ini menujukan bahwa model tersebut sesuai dengan dasar pengambilan keputusan, sehingga regresi ini tidak terjadi heteroskedastisitas. 


\section{Uji Autokolerasi}

Hasil uji autokolerasi menunjukkan bahwa nilai uji Durbin Watson sebesar 1,530. Nilai tersebut akan dibandingkan dengan nilai tabel dengan menggunakan nilai signifikan 5\% jumlah sampel 64(n) dan jumlah independen $4(\mathrm{k}=4)$, didapat nilai $\mathrm{dL}$ 1,466 dan du 1,730. Nilai Durbin Watson dari variabel yang diteliti sebesar 1,530 dimana terletak diantara dL dan du $1,466<1,530<1,730$ yang artinya terletak di daerah keraguan/tanpa keputusan sehingga tidak ada kesimpulan yang pasti. Dalam menentukan apakah terjadi autokolerasi atau tidak maka dilakukan uji run tets dengan taraf signifikansi 0,05 dan hasilnya nilai Asymp. Sig. (2-tailed) sebesar 0,208 yang artinya >0,05 maka tidak terdapat masalah autokolerasi pada data yang diuji.

\section{Analisis regesi Linier Berganda}

Berdasarkan perhitungan SPSS (Statistikal Product And Service Solution) versi 16 diperoleh hasil analisis sebagai berikut :

Hasil Analisis Regresi Linier Berganda Coefficients $^{\mathrm{a}}$

\begin{tabular}{|c|c|c|c|c|c|c|}
\hline & & \multicolumn{2}{|c|}{$\begin{array}{c}\text { Unstandardized } \\
\text { Coefficients }\end{array}$} & \multirow{2}{*}{$\begin{array}{c}\begin{array}{c}\text { Standardized } \\
\text { Coefficients }\end{array} \\
\text { Beta }\end{array}$} & \multirow[b]{2}{*}{ 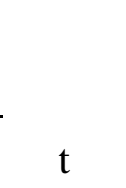 } & \multirow[b]{2}{*}{ Sig. } \\
\hline \multicolumn{2}{|c|}{ Model } & B & Std. Error & & & \\
\hline \multirow[t]{5}{*}{1} & (Constant) & - & 7227.945 & & -1.700 & .094 \\
\hline & FDR & 9241.664 & 3338.874 & .302 & 2.768 & .008 \\
\hline & DER & -4704.842 & 1994.341 & -.233 & -2.359 & .022 \\
\hline & $\mathrm{ROE}$ & 2732.619 & 1094.714 & .275 & 2.496 & .015 \\
\hline & QR & 2246.613 & 957.741 & .235 & 2.346 & .022 \\
\hline
\end{tabular}

a. Dependent Variable: MURABAHAH

Persamaan regresi liner berganda dapat disusun sebagai berikut:

$\mathrm{Y}=-539.343,508+9.241,664 \mathrm{FDR}-4.704,842 \mathrm{DER}+2.732,619 \mathrm{ROE}+2.246,613 \mathrm{QR}$

\section{Koefisien Determinasi}

Berdasarkan hasil analisis regresi linier berganda diperoleh nilai Adjusted $R$ Square sebesar 0,437 dan dihitung menggunakan rumus $\mathrm{R}^{2}$ maka diperoleh hasil sebesar $0,437 \times 100 \%=$ 43,7\%. Dengan ini dapat dikatakan bahwa variabel bebas FDR, DER, ROE dan QR mampu 
menjelaskan perubahan variabel terikat sebesar 43,7\% dan sisanya 56,3\% dijelaskan oleh variabel lain diluar penelitian.

\section{Pengujian Hipotesis}

$\mathrm{H}_{1}$ : $\quad$ Financing To Deposit Ratio (FDR) secara parsial berpengaruh terhadap pembiayaan murabahah pada Bank Umum Syariah tahun 2012-2015.

Dari hasil perhitungan diketahui nilai signifikan variabel FDR sebesar 0,008 hal ini menujukan bahwa nilai variabel FDR 0,008<0,05, yang berarti $\mathrm{H}_{\mathrm{O}}$ ditolak $\mathrm{H}_{\mathrm{a}}$ ditrima. Artinya FDR berpengaruh secara singnifikan dan positif terhadap pembiayaan murabahah. Hasil penelitian ini sesuai dengan hasil penelitian terdahulu yang dilakukan Prastanto (2013) yang menyatakan bahwa Financing To Deposit Ratio (FDR) secara parsial berpengaruh signifikan dan positif terhadap pembiayaan murabahah. Hal ini berarti Financing To Deposit Ratio (FDR) dapat digunakan untuk memprediksi perubahan pembiayaan murabahah dan bisa menjadi salah satu pertimbangan bank syariah dalam menentukan jumlah pembiayaan murabahahah yang harus disalurkan.

$\mathrm{H}_{2}$ : Debt To Equity Ratio (DER) secara parsial berpengaruh terhadap pembiayaan murabahah pada Bank Umum Syariah tahun 2012-2015.

Dari hasil perhitungan diketahui nilai signifikan variabel DER sebesar 0,022 hal ini menujukan bahwa nilai variabel DER 0,022<0,05, yang berarti $\mathrm{H}_{\mathrm{O}}$ ditolak $\mathrm{H}_{\mathrm{a}}$ ditrima. Hasil pengujian tersebut menunjukkan bahwa Debt To Equity Ratio secara parsial berpengaruh signifikan dan negatif terhadap pembiayaan murabahah. Nilai DER yang negatif mengindikasikan bahwa suatu bank dalam menggunakan kewajiban hutangnya dengan sangat lambat. Artinya perputaran dalam menggunakan kewajiban hutang sangat lambat, hal ini menyebabkan kurangnya dana yang bisa disalurkan oleh bank syariah untuk melakukan pembiayaan murabahah. Hasil penelitian ini sesuai dengan hasil penelitian yang dilakukan Arbaian (2008) yang menyatakan bahwa Debt To Equity Ratio secara parsial berpengaruh negatif dan signifikan terhadap pembiayaan murabahah. Hal ini berarti Debt To Equity Ratio (DER) dapat digunakan untuk memprediksi perubahan pembiayaan murabahah dan bisa menjadi salah satu pertimbangan bank syariah dalam menentukan jumlah pembiayaan murabahahah yang harus disalurkan. 
$\mathrm{H}_{3}$ : Return On Equity (ROE) secara parsial berpengaruh terhadap pembiayaan murabahah pada Bank Umum Syariah tahun 2012-2015.

Dari hasil perhitungan diperoleh nilai signifikan variabel ROE sebesar 0,015 hal ini menujukan bahwa nilai variabel $\mathrm{ROE} 0,015<0,05$, yang berarti $\mathrm{H}_{\mathrm{O}}$ ditolak $\mathrm{H}_{\mathrm{a}}$ ditrima. Artinya ROE berpengaruh secara singnifikan dan positif terhadap pembiayaan murabahah. ROE yang semakin meningkat memberikan tanda bahwa kekuatan operasional dan keuangan bank semakin baik, selanjutnya memberikan pengaruh positif terhadap pembiayaan murabahah. Return on Equity bagi bank sangat penting karena hal tersebut untuk mengukur kinerja dari modal sendiri dalam menghasilkan keuntungan. Hasil penelitian ini sesuai dengan hasil penelitian yang dilakukan Prastanto (2013) yang menyatakan bahwa Return on Equity secara parsial berpengaruh signifikan dan positif terhadap pembiayaan murabahah. Return on Equity dapat digunakan untuk memprediksi perubahan pembiayaan murabahah dan bisa menjadi salah satu pertimbangan bank syariah dalam menentukan jumlah pembiayaan murabahahah yang harus disalurkan.

$\mathrm{H}_{4}$ : Quick Ratio (QR) secara parsial berpengaruh terhadap pembiayaan murabahah pada Bank Umum Syariah tahun 2012-2015

Dari hasil perhitungan diperoleh nilai signifikan variabel QR sebesar 0,022 hal ini menujukan bahwa nilai variabel $\mathrm{QR} 0,022<0,05$, yang berarti $\mathrm{H}_{\mathrm{O}}$ ditolak $\mathrm{H}_{\mathrm{a}}$ ditrima. Artinya QR berpengaruh secara singnifikan dan positif terhadap pembiayaan murabahah. Rasio ini sangat penting bagi suatu bank dikarenakan berkaitan dengan mengubah aktiva menjadi kas, sehingga semakin tinggi nilai kas maka semakin banyak dana yang bisa disalurkan untuk pembiayaan murabahah. Hasil penelitian ini sesuai dengan penelitian yang dilakukan Prastanto (2013) yang menyatakan bahwa Quick Ratio (QR) secara parsial berpengaruh signifikan dan positif terhadap pembiayaan murabahah. Quick Ratio dapat digunakan untuk memprediksi perubahan pembiayaan murabahah dan bisa menjadi salah satu pertimbangan bank syariah dalam menentukan jumlah pembiayaan murabahahah yang harus disalurkan. 


\section{Pengujian Hipotesis secara Simultan (Uji F)}

$\mathrm{H}_{5}$ : $\quad$ Financing To Deposit Ratio (FDR), Debt To Equity Ratio (DER), Return On Equity (ROE) dan Quick Ratio (QR) secara simultan berpengaruh terhadap pembiayaan murabahah pada Bank Umum Syariah tahun 2010 - 2013.

Dari hasil perhitungan diperoleh nilai signifikan adalah 0,000. Hal ini menujukan bahwa nilai signifikan FDR, DER, ROE dan $\mathrm{QR}$ 0,000<0,05 yang berarti $\mathrm{H}_{\mathrm{O}}$ ditolak dan $\mathrm{H}_{\mathrm{a}}$ ditrima , artinya keempat variabel bebas FDR, DER, ROE dan QR secara bersama-sama (simultan) berpengaruh signifikan terhadap pembiayaan murabahah. Dengan nilai Adjusted $\mathrm{R}^{2}$ sebesar 0,437 yang berarti bahwa kemampuan variabel independen yaitu FDR, DER, ROE dan QR dalam menjelaskan variasi variabel dependen yaitu pembiayaan murabahah amat terbatas yaitu sebesar 43,7\%, sedangkan 56,3\% dijelaskan oleh faktor lain yang tidak dimasukan dalam penelitian ini.

\section{SIMPULAN DAN SARAN}

\section{Simpulan}

Dari hasil uji asumsi klasik, berdasarkan analisis grafik dan statistik menunjukkan bahwa data terdistribusi normal, model ini juga tidak ada masalah multikoloritas dan tidak terdapat masalah autokorelasi, persamaan regresi ini juga tidak terdapat heteroskedastisitas. Dari hasil tersebut dapat disimpulkan bahwa model ini telah memenuhi syarat uji asumsi klasik untuk dilakukannya analisis regrensi linier berganda.

Berdasarkan hasil uji hipotesis, dapat disimpulkan bahwa secara parsial FDR berpengaruh signifikan dan positif terhadap pembiayaan murabahah pada Bank Umum Syariah. Sehingga semakin tinggi nilai FDR maka semakin tinggi pula nilai pembiayaan murabahah dan sebaliknya. DER berpengaruh signifikan dan negatif terhadap pembiayaan murabahah pada Bank Umum Syariah. Sehingga semakin tinggi nilai DER maka semakin rendah nilai pembiayaan murabahah dan sebaliknya. ROE berpengaruh signifikan dan positif terhadap pembiayaan murabahah pada Bank Umum Syariah. Sehingga semakin tinggi nilai ROE maka semakin tinggi pula nilai pembiayaan murabahah dan sebaliknya. QR berpengaruh signifikan dan positif terhadap pembiayaan murabahah pada Bank Umum Syariah. Sehingga semakin tinggi nilai QR maka semakin tinggi pula nilai pembiayaan murabahah dan sebaliknya. Secara simultan menunjukkan bahwa FDR, DER, ROE dan QR 
secara bersama-sama berpengaruh terhadap pembiayaan murabahah pada Bank Umum Syariah.

\section{Saran}

Bank syariah diharapkan agar mempertimbangkan variabel-variabel lain untuk menentukan jumlah pembiayaan murabahah yang akan dikeluarkan, karena variabel FDR, DER, ROE dan QR hanya menyumbang 43,7\% dalam mempengaruhi pembiayaan murabah. Bank syariah hendaknya juga mengembangkan produk-produk pembiayaan lain yang lebih inovatif sehingga permintaan akan produk pembiayaan tersebut meningkat dari tahun ke tahun.

\section{DAFTAR PUSTAKA}

Antonio, Muhammad Syafi’i. 2001. Bank Syariah: Dari Teori Ke Praktik. Jakarta: Gema Insani Press.

Cleopatra, Yuria Pratiwhi. 2008. Faktor-faktor yang Mempengaruhi Pertumbuhan Proporsi Aset Perbankan Syariah di Indonesia. Dalam Jurnal Ekonomi dan Bisnis. Jakarta: UI.

Laksmana, Yusak. 2009. Tanya Jawab: Cara Mudah Mendapatkan Pembiayaan di Bank Syariah. Jakarta: PT Elex Media Komputindo.

Muhammad. 2005. Pengantar Akuntansi Syariah. Jakarta: Salemba Empat.

Nurhayati, Sri dan Wasilah. 2009. Akuntansi Syariah Di Indonesia. Jakarta: Salemba Empat.

Statistik Perbankan Syariah. Bank Indonesia (Online), tersedia: http://www.bi.go.id, diunduh 25 Agustus 2015.

Ikatan Akuntansi Indonesia, 2007, “Standar Akuntansi Keuangan PSAK No. 102” Salemba Empat, Jakarta.

Wibowo, M. Ghafur. 2007. Pengaruh Rasio Keuangan Bank Terhadap Pembiayaan Bank Syariah. Yogyakarta.

Prastanto. 2013. Pengaruh Financing To Deposit Ratio (FDR), Non Performing Financing (NPF), Debt To Equity Ratio (DER), Quick Ratio (QR), Dan Return On Equity (ROE) Terhadap Pembiayaan Murabahah Pada Bank Umum Syariah Di Indonesia. Semarang.

Undang-undang tentang Perbankan. Bank Indonesia (Online), tersedia: http://www.bi.go.id, diunduh 25 Agustus 2015.

Karim, Adiwarman, 2006. “Bank Islam: Analisis Fikih dan Keuangan”, Penerbit: PT Raja Grafindo Persada, Jakarta.

Suhendi, 2002. Fiqh Muamalah, Penerbit: PT Raja Grafindo Persada, Jakarta.

Sugiyono. 2011. Metode Penelitian kuantitatif, kualitatif, dan RdanD. Bandung: Alfabeta.

Pratin dan Akhyar Adnan. 2005. "Analisis Hubungan Simpanan, Modal Sendiri,NPL, Prosentase Bagi Hasil dan Markup Keuntungan terhadap Pembiayaan pada Perbankan Syariah (studi kasus pada BMI)”. Dalam Sinergi Kajian Manajemen 
dan Bisnis, Edisi Khusus on Finance. Hal 35-52 Yogyakarta: Balai Diklat Keuangan III Yogyakarta dan FE UII.

Sekaran. 2006. Metode Penelitian untuk Bisnis, Edisi 4. Jakarta: Salemba Empat.

Sulistri, Enik. 2009. “Analisis Rasio Keuangan Untuk Menilai Kinerja Keuangan Perbankan Syariah (2003-2007)”. Surakarta: Skripsi Program Sarjana Fakultas Ekonomi Universitas Muhamadiyah Surakarta

Usamah. 2009. "Peran Kompetensi dan Model Pengorganisasian Dewan Pengawas Syariah Terhadap Pembiayaan Berbasis Bagi Hasil Pada Perbankan Syariah di Indonesia”. Dalam Artikel KU. Semarang: Undip.

Triyuwono, Iwan. 1996. Teori Akuntansi Berhadapan Nilai-nilai ke Islaman. Dalam Jurnal Ulumul Quran Nomor 5 VOL VI Tahun1996.

Sugiyono. 2011. Metode Penelitian kuantitatif, kualitatif, dan R dan D. Bandung: Alfabeta. Sugiyono. 2014. Statistic untuk penelitian. Bandung: Alfabeta. 